\title{
Dishkeya gen. nov., a New World endemic genus of leaf-mining Tischeriidae (Lepidoptera), transferred from Tischeria Zeller
}

\author{
Jonas R. Stonis ${ }^{1}$, \\ M. Alma Solis ${ }^{2}$ \\ ${ }^{1}$ Institute of Ecology, \\ Nature Research Centre, \\ Akademijos St. 2, \\ Vilnius 08412, Lithuania \\ ${ }^{2}$ Systematic Entomology Laboratory, \\ ARS, US Department of Agriculture, \\ National Museum \\ of Natural History, \\ Smithsonian Institution, \\ Washington, D. C., \\ 20013-7012, USA
}

\begin{abstract}
We describe a new genus, Dishkeya Stonis, gen. nov., and a new species, Dishkeya gothica Diškus \& Stonis, sp. nov., discovered feeding on Gouania lupuloides (L.) Urb., Rhamnaceae. We discuss the diagnostics of Tischeria Zeller and Dishkeya gen. nov.; the latter is characterized by the absence of a juxta, the presence of a pseudognathos, and well-developed carinae of the phallus in the male genitalia. We newly combine Tischeria bifurcata Braun and Tischeria gouaniae Stonis \& Diškus with Dishkeya and designate the latter species as the type species of the new genus. All species treated in the paper are illustrated with drawings or photographs of the male genitalia.
\end{abstract}

Keywords: juxta, new species, pseudognathos, trumpet moths

\section{INTRODUCTION}

Tischeriidae, or trumpet moths, represent an almost cosmopolitan family of the so-called Microlepidoptera (Insecta: Lepidoptera). In comparison to many other families of moths, Tischeriidae is a relatively small family. At present only about 150 Tischeriidae species have been described worldwide, excluding Australia and New Zealand. However, many new species still await discovery and taxonomic description, particularly for the areas of South East Asia and tropical America that are poorly surveyed. The larvae of trumpet moths are obligatory leaf miners of plants, i.e. they live (even pupate) and feed inside of plant tissues. Adults possess numerous peculiar morphological characters, including long antennal sensillae tricho-

\footnotetext{
* Corresponding author. Email: stonis.biotaxonomy@gmail.com
}

dea on the male antenna, a modified phallus in the male genitalia, or ovipositor lobes covered with thickened peg-like setae along with unique rod-like or plate-like projections known as prela in the female genitalia. For detailed morphological and biological characterization of this lepidopteran group, see Braun, 1972; Puplesis, Diškus, 2003; Stonis et al., 2018.

Before this study, the family Tischeridae was comprised of four genera: Tischeria Zeller, 1839, Coptotriche Walsingham, 1890 (restored to generic status by Puplesis, Diškus, 2003), Astrotischeria Puplesis \& Diškus, 2003, and Paratischeria Diškus \& Stonis, 2017. A diagnostic scheme for generic differentiation was provided by $\mathrm{Xu}$ et al. (2017). Some diagnoses of Tischeria, Coptotriche, and Astrotischeria can be also found in Puplesis \& Diškus (2003) and a diagnosis of Paratischeria was provided by Stonis et al. (2017). 
In this paper, we discuss the diagnostics of Tischeria Zeller. Based on the absence of the juxta, the presence of a pseudognathos, and well-developed carinae of the phallus in the male genitalia, we exclude the Nearctic Tischeria bifurcata Braun and Neotropical T. gouaniae Stonis \& Diškus from Tischeria, and describe a new genus, Dishkeya Stonis, gen. nov. We also illustrate genital structures of the male genitalia of D. bifurcata (Braun), comb. nov., and D. gouaniae (Stonis \& Diškus), comb. nov., and describe one new species, D. gothica Stonis \& Diškus, sp. nov.

\section{MATERIALS AND METHODS}

The documentation of taxa and description of the new species are based on the material deposited in the collections of the Natural History Museum, London, U.K. (NHMUK) and the Zoological Museum of the University of Copenhagen, Copenhagen, Denmark (ZMUC).

The following protocols for Tischeriidae have been previously outlined: collecting by Stonis et al. (2018), species identification and description by Puplesis, Diškus (2003), and for techniques of specimen dissection by Stonis et al. (2014). Permanent preparations on microscope slides were photographed and studied with a Leica DM2500 microscope and Leica DFC420 digital camera.

\section{DIAGNOSIS OF TISCHERIA ZELLER BASED ON MORPHOLOGY OF MALE GENITALIA}

Diagnosis. Within Tischeriidae, Tischeria represents one of the most distinctive phylogenetic lineages at the generic rank, with females possessing an antrum in the female genitalia. In the male genitalia, the genus is characterized by:

1) a distinctly long uncus with two large lateral lobes (shared with Coptotriche Walsingham and the majority of Paratischeria Diškus \& Stonis, but not with Astrotischeria Puplesis \& Diškus, except for a few aberrant Astrotischeria species);
2) distinctive socii, membranous, paired, covered with tiny spines (shared with all other genera, except for some non-Tischeria species discussed below);

3) a spineless diaphragm (except Tischeria sichotensis Ermolaev) (shared with Astrotischeria and Paratischeria, but spined in Coptotriche);

4) an absent gnathos (shared with Astrotischeria, Paratischeria, and some non-Tischeria species with a pseudognathos, discussed below, and some unpublished species by Stonis et al., in prep.);

5) a slender and simply shaped valva (shared with the majority of Paratischeria; but not with Coptotriche, few Paratischeria, and some nonTischeria species, discussed separately (Stonis, Diškus, submitted);

6) an absent anellus (not shared with $A s$ trotischeria, Paratischeria, and most of Coptotriche);

7) an absent transtilla (shared with some Astrotischeria and Paratischeria but not with Coptotriche);

8) a ventral lobe of the vinculum large or moderately large, usually triangular (shared with some Coptotriche, Astrotischeria, and $\mathrm{Pa}$ ratischeria, but not with the majority of Astrotischeria and Paratischeria;

9) a phallus large or moderately large, bifid in apical half, and rounded basally (shared with some Astrotischeria and Paratischeria, but not with Coptotriche and the majority of Astrotischeria, Paratischeria, some non-Tischeria species discussed separately (Stonis, Diškus, submitted);

10) spines of the phallus absent (shared with some Astrotischeria and Paratischeria, but not with Coptotriche and a few Astrotischeria and Paratischeria);

11) carinae of the phallus absent (shared with Coptotriche and almost all Astrotischeria, and Paratischeria; but not with some nonTischeria species, discussed below).

However, among the characters which diagnose the genus, one character is particularly striking and diagnostically important; it is not shared with any other genus, and supports the monophyly of Tischeria: 
(12) the presence of the juxta, which is always well-sclerotized, greatly elaborated, and horn-like. The juxta varies at the species level and is the most important and useful character for species differentiation in Tischeria.

Taxa contradicting the diagnostic concept of Tischeria. Characteristics of some species, previously included in Tischeria, do not fit the diagnosis of the genus. It also applies to some species previously listed in a review of the American Tischeria by Stonis, Diškus (2007), specifically Tischeria bifurcata Braun, 1915, and T. gouaniae Stonis \& Diškus, 2007. These two species have no juxta (which is the major diagnostic character of Tischeria), socci are greatly modified, and the phallus possesses carinae, which are not usual for Tischeria (Note: Old World species in contradiction to the diagnosis of Tischeria are discussed separately by Stonis, Diškus, ms. submitted). By keeping such species in Tischeria, we would allow the genus to be paraphyletic and make generic diagnostics of Tischeriidae complicated and inconvenient for users. Therefore, we exclude T. bifurcata and T. gouaniae from Tischeria and erect a new genus for these species. The new genus is characterized by unique, derived characters (hypothesized apomorphies). The concept of the new genus is also supported by our discovery of a third distinctive, new species possessing exactly the same derived characters as other species of Dishkeya, gen. nov., T. bifurcata and T. gouaniae.

\section{DESCRIPTION OF A NEW GENUS, WITH A REVIEW OF INCLUDED SPECIES}

\section{Dishkeya Stonis, gen. nov. \\ http://zoobank.org/D22BCAB9-8A77-4950- B723-164006F15969}

Type species. Dishkeya gouaniae (Stonis \& Diškus, 2007).

Diagnosis. External characters or characters of wing venation are not informative or insufficient for generic differentiation in most cases of Tischeriidae, including this new genus. In the male genitalia, the presence of a unique pseudognathos, which is derived from socii, greatly developed lateral processes of phallus, and pres- ence of carinae of the phallus distinguish the new genus from all other genera of Tischeriidae. Dishkeya also differs from Tischeria, the most similar genus, in the absence of the juxta (Fig. 1). The linear leaf mines of Dishkeya also make it distinctive because the majority of Tischeriidae produce blotch-like leaf mines. However, leaf mines of only two species of the new genus are known, and there are a few cases of linear leaf mines in a few other species of Tischeriidae.

Description. Adult. Very small moths: forewing length $2.3-4.0 \mathrm{~mm}$, wingspan $5.0-$ $8.5 \mathrm{~mm}$. Head: frons smoothly scaled; frontal tuft overlapping the frons, comprised of long, slender lamellar and piliform scales; collar comprised of slender lamellar scales; antenna longer than one half of the length of forewing. Forewing without a distinctive pattern, from yellowish ochre to pale grey, irregularly speckled with some darker scales; fringe line absent; hindwing slender, usually grey or pale brownish or ochreous cream, without androconia. Abdomen with anal tufts.

Male genitalia. Capsule significantly longer than wide. Uncus with two large lateral lobes. Socii derived, forming a pseudognathos (Fig. 1). Valva slender, with short transverse lobes or without lobes; transtilla absent. Juxta absent. Anellus absent. Vinculum with a large, distally rounded or truncated ventral lobe. Phallus broadly bifurcated in apical half, with strongly developed and variously elaborated lateral processes, and carinae (Fig. 1).

Bionomics. The host plants are from the Rhamnaceae family: Ceanothus L. and Gouania spp., including G. polygama (Jacq.) Urb. and G. lupuloides (L.) Urb. Larvae mine leaves in March-April, and June-September; larvae of at least two species produced linear leaf mines.

Distribution. Currently known from the south-eastern USA, a tropical forest in Belize, the Yungas biogeographical province of Bolivia (see Discussion), and from elevations of a few metres at sea level in California, USA, to $1700 \mathrm{~m}$ in the Andes of South America.

Etymology. The genus is named in honour of Dr Arūnas Diškus (Vilnius, Lithuania) in recognition of his outstanding contributions 


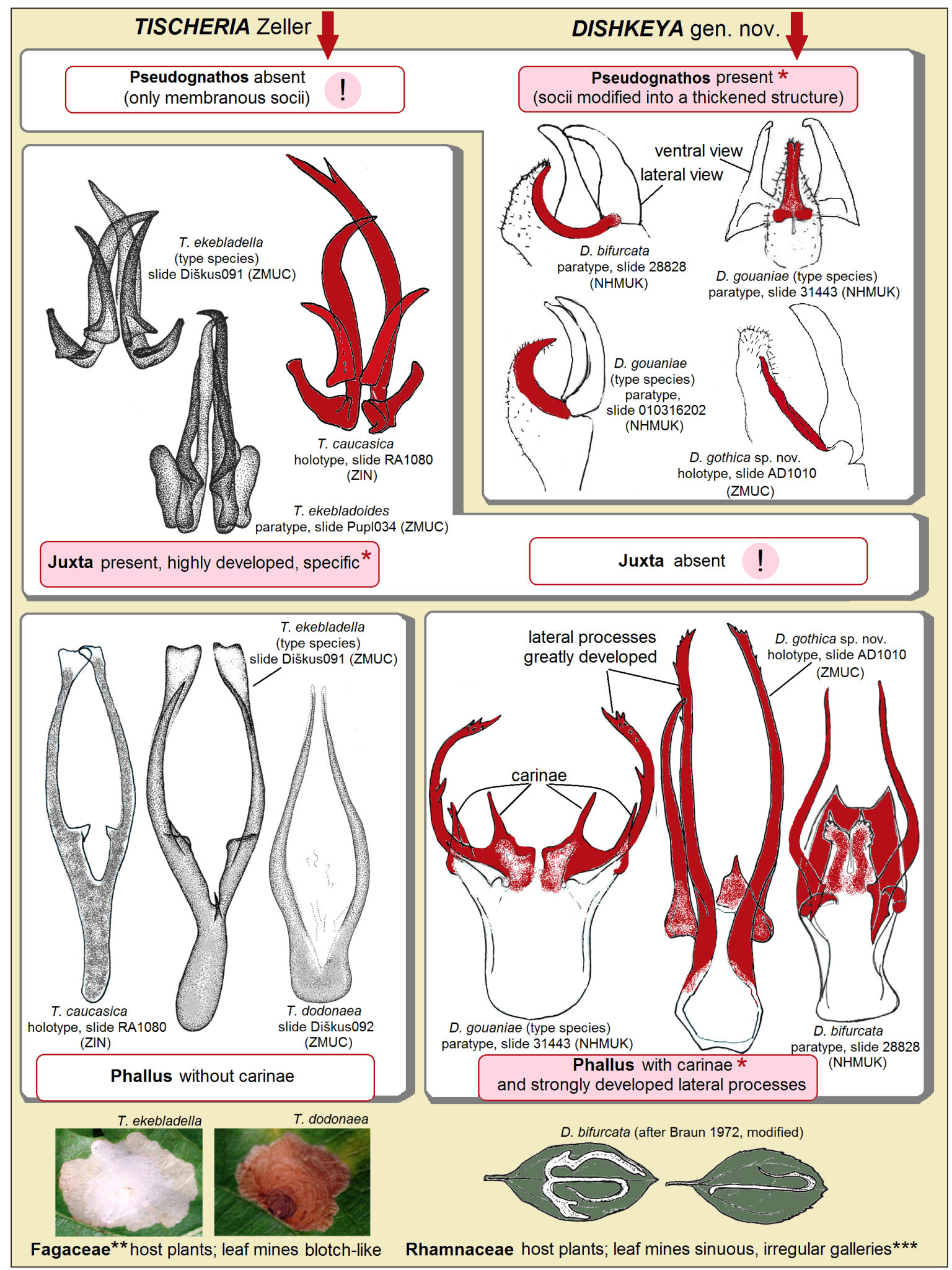

Fig. 1. Diagnostics of Tischeria Zeller and Dishkeya gen. nov.; morphological structures are drawn to different scales (Notes: ${ }^{*}$ - hypothesized apomorphies; ${ }^{* *}$ - an updated review of Tischeria is under preparation and the host plants of confirmed Tischeria are mostly from Fagaceae; however, there are exceptions, see Discussion; ${ }^{* *}$ - leaf mines of only two species from three Dishkeya are known; linear leaf mines are also found in other Tischeriidae species 
to Tischeriidae and Nepticulidae research and his remarkable enthusiasm for Tischeridae inventories, especially in tropical countries. We also congratulate him on his 50th birthday and achievement of 30 years in the field of leaf miner research.

\section{Dishkeya bifurcata (Braun, 1915) (new com- bination)}

Tischeria bifurcata Braun, 1915: 273.

Tischeria bifurcata Braun, in Braun 1972: 91-93; in Stonis, Diškus, 2007: 1287.

Material examined. $1 \lesssim$ (paratype), USA, California, Fredalba, 2.ix.1912, reared on Ceano- thus sp., leg. A. F. Braun, genitalia slide no. 28828 (NHMUK).

Diagnosis. External characters are variable (Braun, 1972) and therefore not informative for species identification (Fig. 2). In the male genitalia, the Nearctic Dishkeya bifurcata is most similar to the Neotropical D. gouaniae (Stonis \& Diškus); see Diagnosis of D. gouaniae.

Bionomics. The host plants are various species of Ceanothus L., including C. arboreus Greene (Rhamnaceae). Larvae mine leaves in March-April, July, and September. The leaf mine has a linear or corridor shape (described and illustrated by Braun, 1972: 93: fig. 55). Pupation occurs in the part of mine that lies over

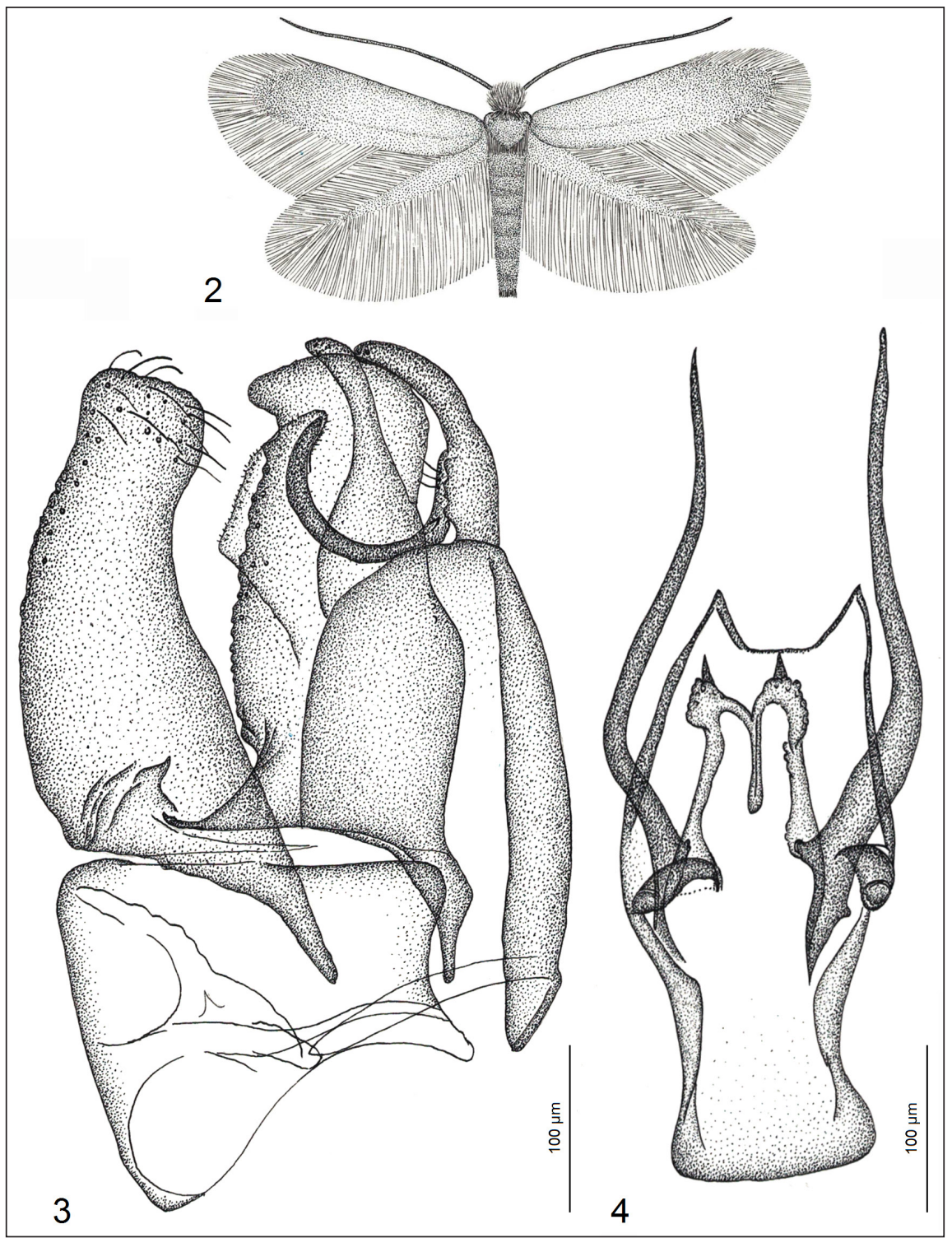

Figs. 2-4. Paratype of Dishkeya bifurcata (Braun), USA, California, Fredalba, 2.ix.1912, reared on Ceanothus sp., leg. A. F. Braun, genitalia slide no. 28828, deposited at NHMUK. 2 - male adult, 3 - male genitalia, capsule with phallus removed, lateral view; 4 - same, phallus, ventral view 
the midrib of the leaf (Braun, 1972). Adults fly in March-April and July-September.

Remarks. The species was re-described and illustrated by Braun, 1972: 91-93, Figs. 11, 55, $101,146)$. Here, based on the studied paratype no. $010316202{ }^{\lambda}$ (NHMUK), we provide detailed documentation of the male genitalia (Figs. 3, 4), including the first lateral view of the male genital capsule (Fig. 3).

Braun (1972) pointed out that the moths of this species are different with respect to size and vary extremely in coloration of forewings; however, the genitalia were found to be identical. We noticed that the illustration of the male genitalia provided by Braun, 1972: fig. 101 differs slightly from the paratype that we studied at NHMUK. The male paratype that we studied came from the same series and locality as the holotype by Braun 1915, i.e. California: Fredalba.

Distribution. Known from the United States: California and Arizona.

\section{Dishkeya gouaniae (Stonis \& Diškus, 2007) (new combination)}

Tischeria gouaniae Stonis \& Diškus, 2007: 1287-1291.

Material examined. $4 \hat{\sigma}$ (holotype and paratypes), Belize, Cayo Distr., Chiquibul Forest

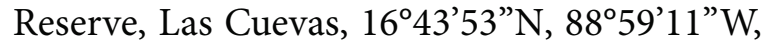
$550 \mathrm{~m}$, mining larvae on Gouania polygama (Jacq.) Urb. (Rhamnaceae), 25.ix.1997 and 19.iii-3.vii.1998, leg. O. T. Lewis, genitalia slide numbers: $31442 \hat{\jmath}$ (holotype), 31443 $\hat{\partial}$, $010316202{ }^{\Uparrow}$ (NHMUK).

Diagnosis. External characters are not useful for species identification (Fig. 5). In the male genitalia, Dishkeya gouaniae is most similar to the Nearctic D. bicurcata (Braun). However, D. gouaniae is distinguishable from the latter by the widely rounded vinculum, wide phallus, and slender carinae of the phallus (also see Diagnosis of $D$. gothica sp. nov.).

Bionomics. The host plant is Gouania polygama (Jacq.) Urb. (Rhamnaceae). Larvae mine leaves in March-April, June, July, August, and September. The leaf mine has a linear or corridor shape (not preserved by the collector; O. T. Lewis pers. comm.). Adults fly in March-September. Otherwise, biology is unknown.

Remarks. The species was described and illustrated by Stonis \& Diškus 2007: 1287-1291, Figs. 2, 3A, B, C, 4A, B. Here, based on paratype no. 010316202^ (NHMUK), we provide detailed documentation of the male genitalia (Figs. 6-12), including the first photographic documentation the lateral view of the male genitalia (Figs. 9, 11, 12).

Distribution. Known from Central America (Belize: Las Cuevas), at an elevation of about $500 \mathrm{~m}$.

\section{Dishkeya gothica Diškus \& Stonis, sp. nov.}

http://zoobank.org/C5A4EB82-BE04-4962A152-8EF42E5A25CA

Type material. Holotype: $\widehat{\partial}$ (genitalia from adult in pupal skin, no pinned adult preserved), Bolivia: Nor Yungas Province, Coroico, $16^{\circ} 12^{\prime} 25^{\prime \prime} \mathrm{S}, 67^{\circ} 43^{\prime} 53^{\prime \prime} \mathrm{W}$, elevation $1680 \mathrm{~m}$, mining larva on Gouania lupuloides (L.) Urb. (Rhamnaceae) 15.vi.2018, field card no. 5260, A. Diškus, genitalia slide no. AD1010 (ZMUC).

Diagnosis. In the male genitalia, the unique phallus (Fig. 13), valva with a short inner lobe (Fig. 18), and a well-chitinized, truncated vinculum (Fig. 17) distinguish this species from all other currently known species, including another Neotropical Gouania-feeding species, D. gouaniae (see above).

Male. Known from adult in pupal skin; only genitalia are preserved and described (Figs. 25, 26).

Genitalia (Figs. 13-24). Capsule significantly longer $(390 \mu \mathrm{m})$ than wide $(155 \mu \mathrm{m})$. Uncus (Fig. 16) with two large lateral lobes. Socii modified (Fig. 18), forming a chitinized pseudognathos, better visible from the lateral view (Figs. 21, 22). Valva (Figs. 13, 18, 20) about $300 \mu \mathrm{m}$ long (excluding the basal process), with an inner lobe (Figs. 18, 20). Transtilla and juxta absent. Vinculum heavily chitinized, with distally truncated ventral plate 


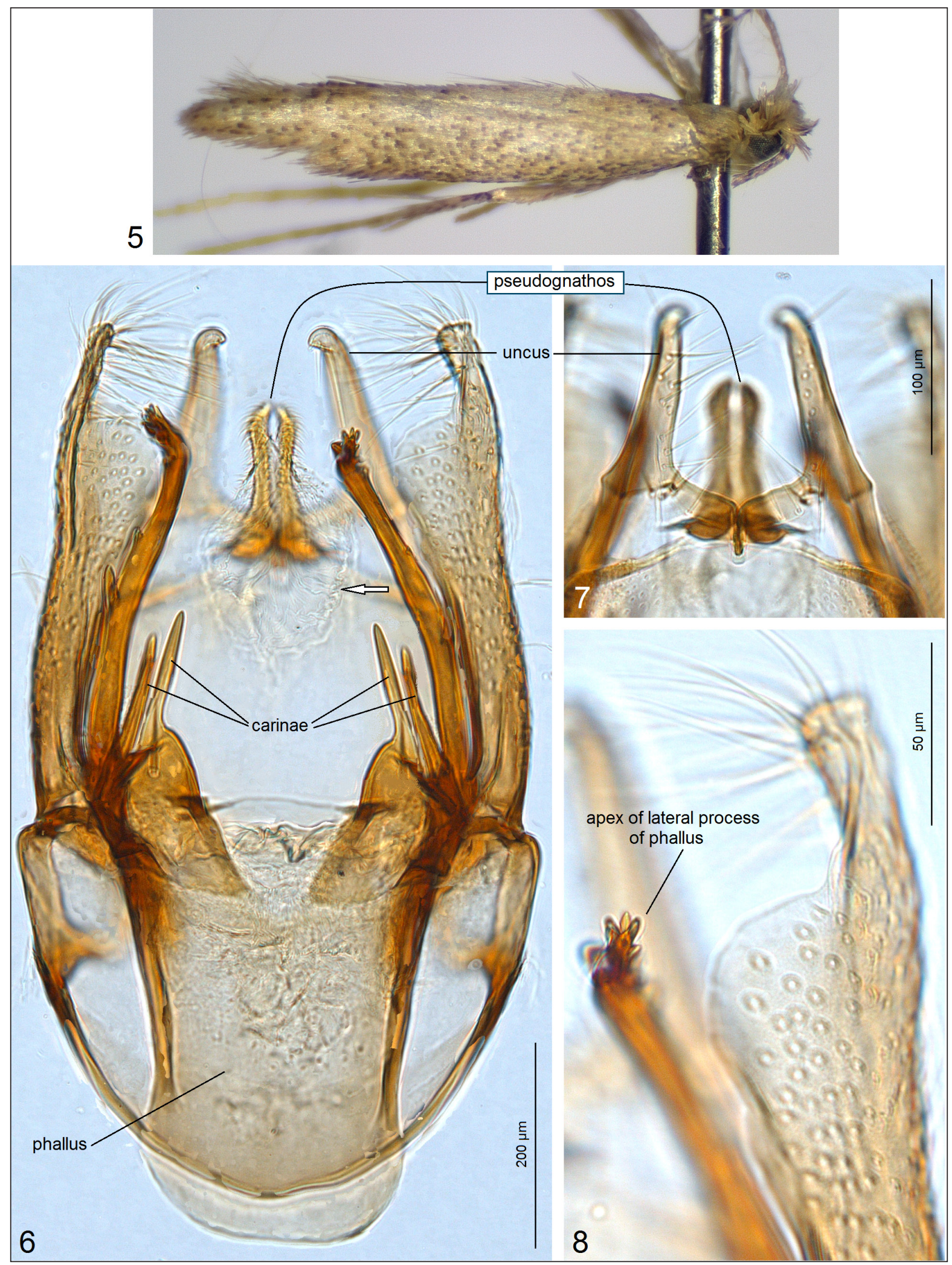

Figs. 5-8. Paratype of Dishkeya gouaniae (Stonis \& Diškus), type species of Dishkeya, Belize, genitalia slide no. 010316202 , deposited at NHMUK. 5 - male adult, 6 - male genitalia, ventral view of capsule with phallus removed; 7 - same, uncus; 8 - same, apices of right valva and lateral process of phallus 


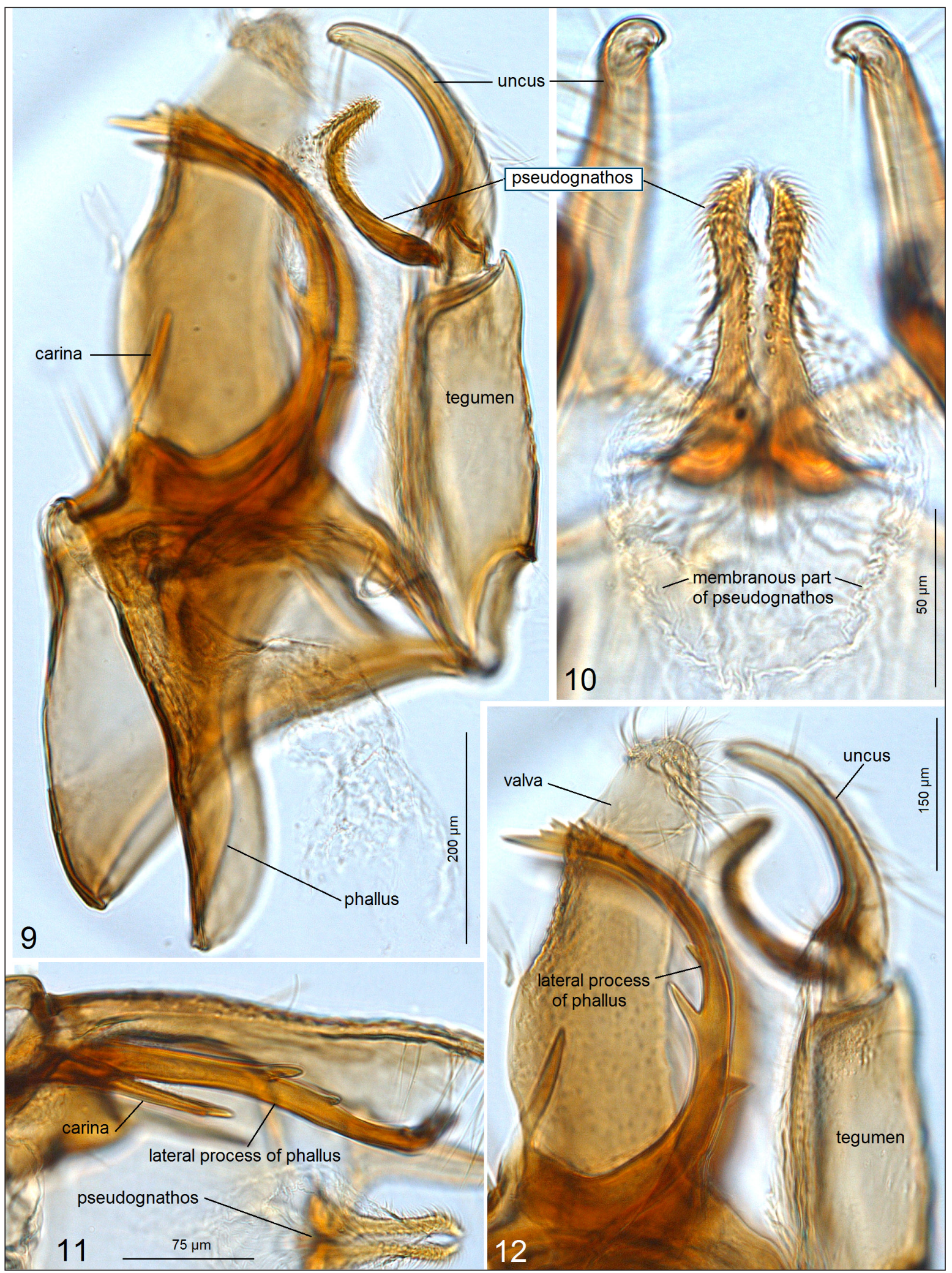

Figs. 9-12. Male genitalia of Dishkeya gouaniae (Stonis \& Diškus), type species of Dishkeya, Belize, genitalia slide no. 010316202, deposited at NHMUK. 9 - lateral view of capsule with phallus inside; 10 - same, pseudognathos; 11 - lateral view of carina and lateral process of phallus; 12 - lateral view of uncus, valva and lateral process of phallus 


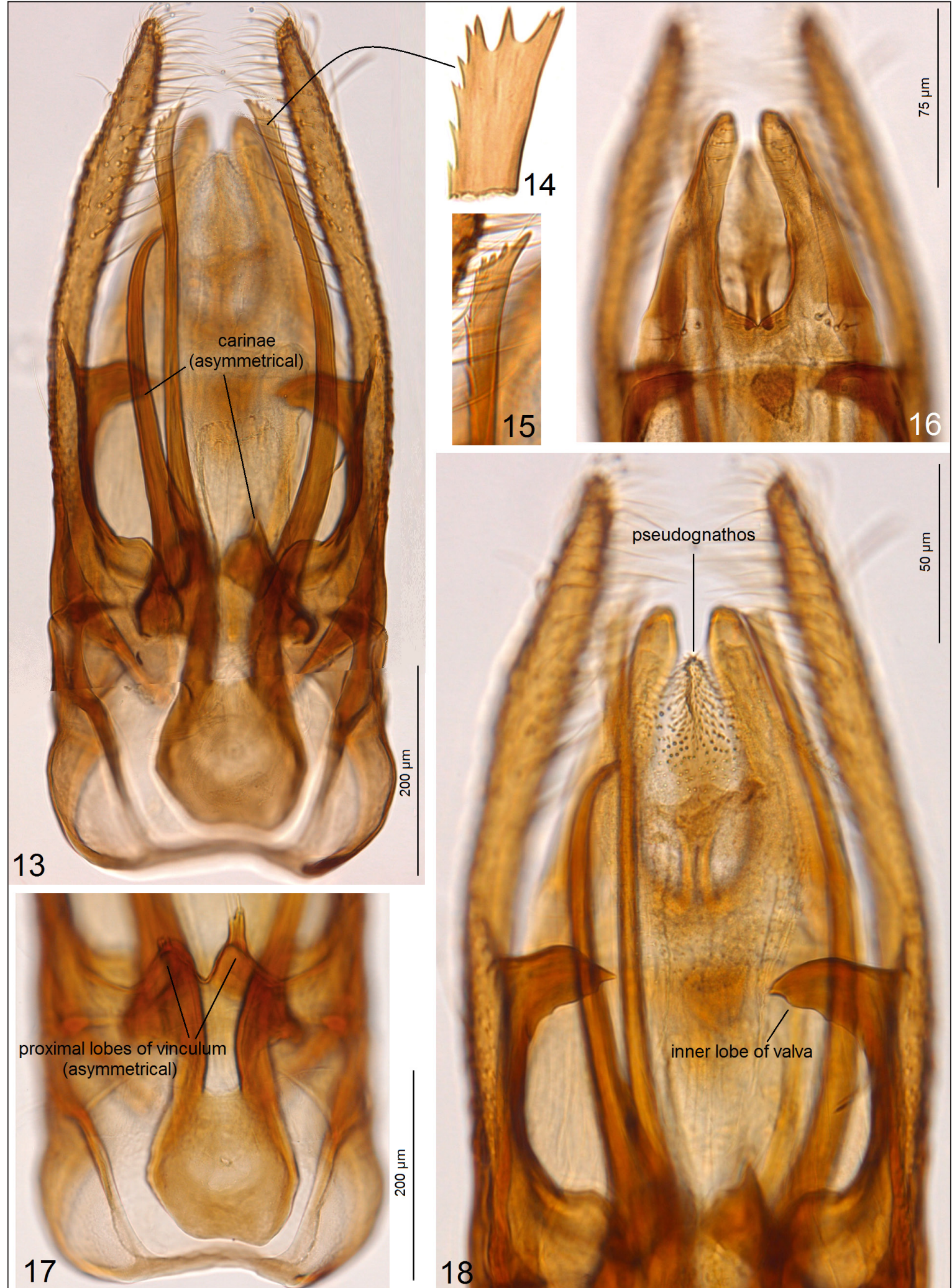

Figs. 13-18. Male genitalia of the holotype of Dishkeya gothica Diškus \& Stonis, Bolivia, deposited at ZMUC. 13 - ventral view of capsule with phallus inside; 14, 15 - same, apex of lateral process of phallus; 16 - same, uncus; 17 - basal part of phallus and vinculum; 18 - apical half of capsule, focused on inner lobes of valvae and modified socii (pseudognathos) 


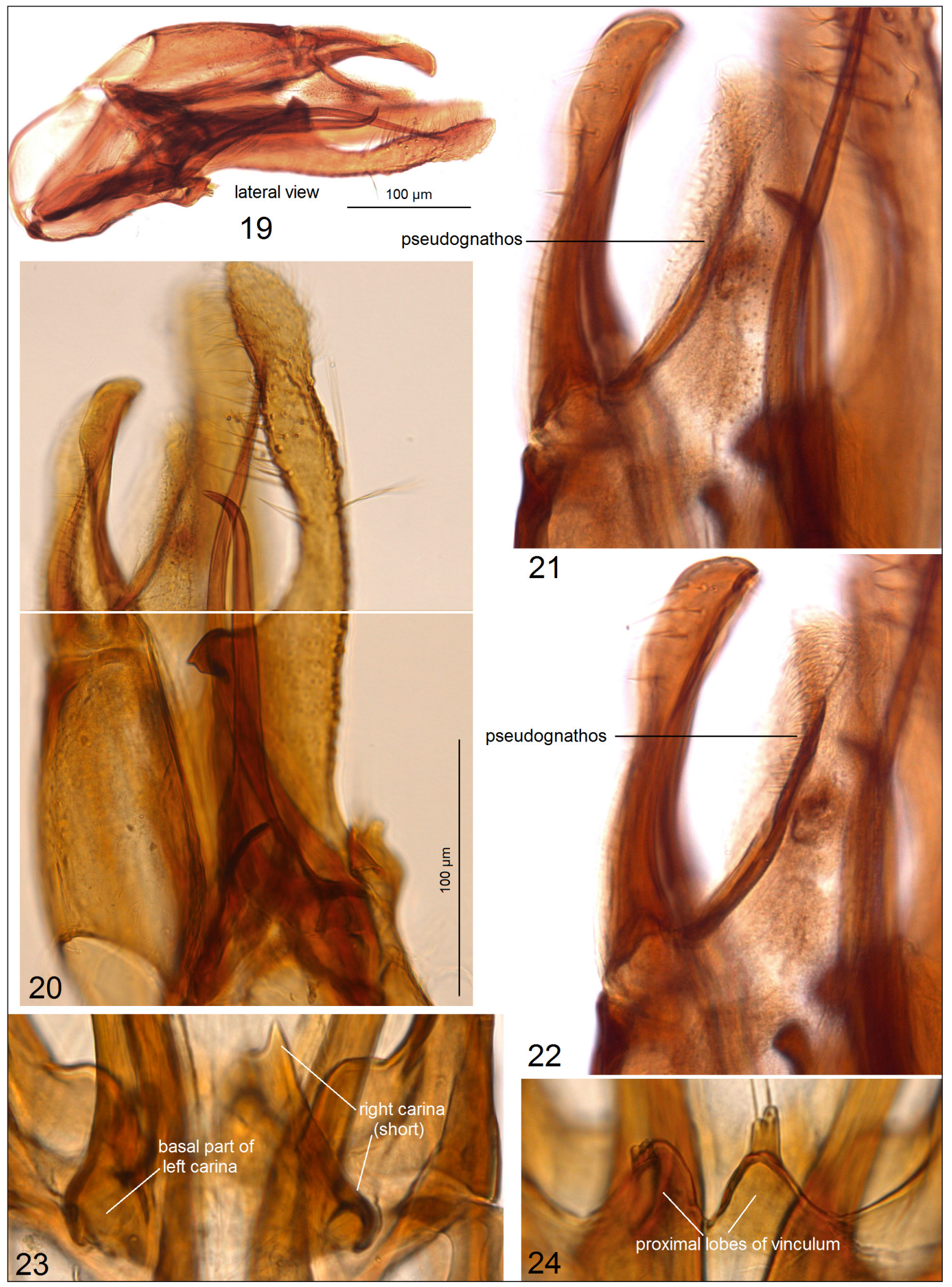

Figs. 19-24. Male genitalia of the holotype of Dishkeya gothica Diškus \& Stonis, Bolivia, genitalia slide no. AD1010, deposited at ZMUC. 19 - lateral view of capsule with phallus inside; 20 - same, apical half of capsule; 21, 22 - same, uncus and pseudognathos; 23 - basal part of carinae of phallus; 24 - proximal lobes of vinculum with asymmetrical papillae 
(Fig. 17), proximally with two asymmetrical, papillated lobes (Fig. 24). Phallus (Fig. 13) about $335 \mu \mathrm{m}$ long (including the lateral processes), with two very long, distally dentate lateral processes (Figs. 14, 15); carinae distinctly asymmetrical (Figs. 13, 23).

Bionomics. The host plant is Gouania lupuloides (L.) Urb., Rhamnaceae. Larvae mine leaves in June. Leaf mine is unstudied and undocumented (not preserved by the col- lector). Adults fly in July. Pupa illustrated in Figs. 25, 26.

Distribution. Currently known from a single locality in Bolivia, Nor Yungas Province, Coroico, at the elevation of ca. $1700 \mathrm{~m}$.

Etymology. The species name is derived from Late Latin gothicus in reference to the elaborate, structurally overcrowded male genitalia that slightly resemble medieval architecture.

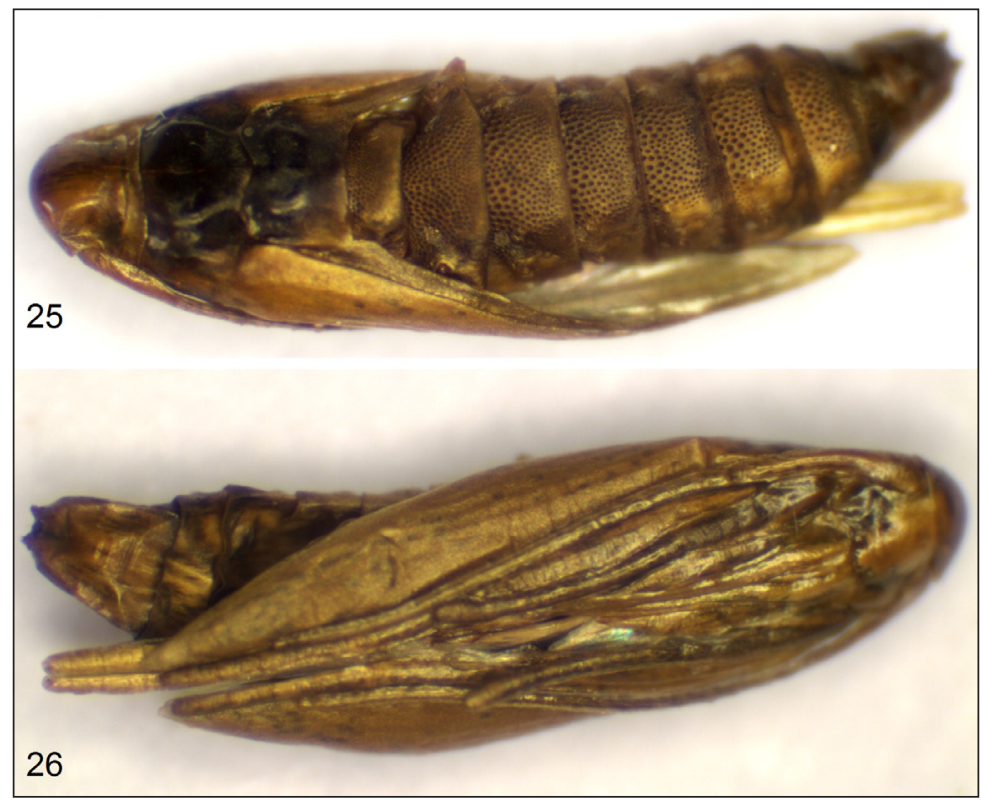

Figs. 25-26. Pupa of Dishkeya gothica Diškus \& Stonis. 25 - dorsal view; 26 - ventral view

\section{DISCUSSION}

Previously, the carinae on the phallus of Dishkeya gouaniae were mistaken as derivates of the juxta (Stonis, Diškus, 2007) and, therefore, it was assumed that D. gouaniae with D. bifurcata belonged to Tischeria, forming a distinctive species group within the genus. We found that the juxta is absent in Dishkeya and we hypothesize that the pseudognathos (derived from socii) and great modifications of the phallus are apomorphies.

All three currently known Dishkeya species are trophically associated exclusively with Rhamnaceae. The host plants of "true"
Tischeria (excluding some non-Tischeria species, Stonis, Diškus, in prep.) mostly belong to Fagaceae, predominantly various species of Quercus (an updated review of Tischeria is under preparation; Diškus, pers. comm.). Nevertheless, there are two American Tischeria species which utilize Rhamnaceae along with the currently described Dishkeya.

Currently, the genus is known from few geographically separated areas (Fig. 27). We expect that the genus may have an almost continuous distribution at least along the West coast of the Americas, and most likely more species of Dishkeya will be discovered in future. 


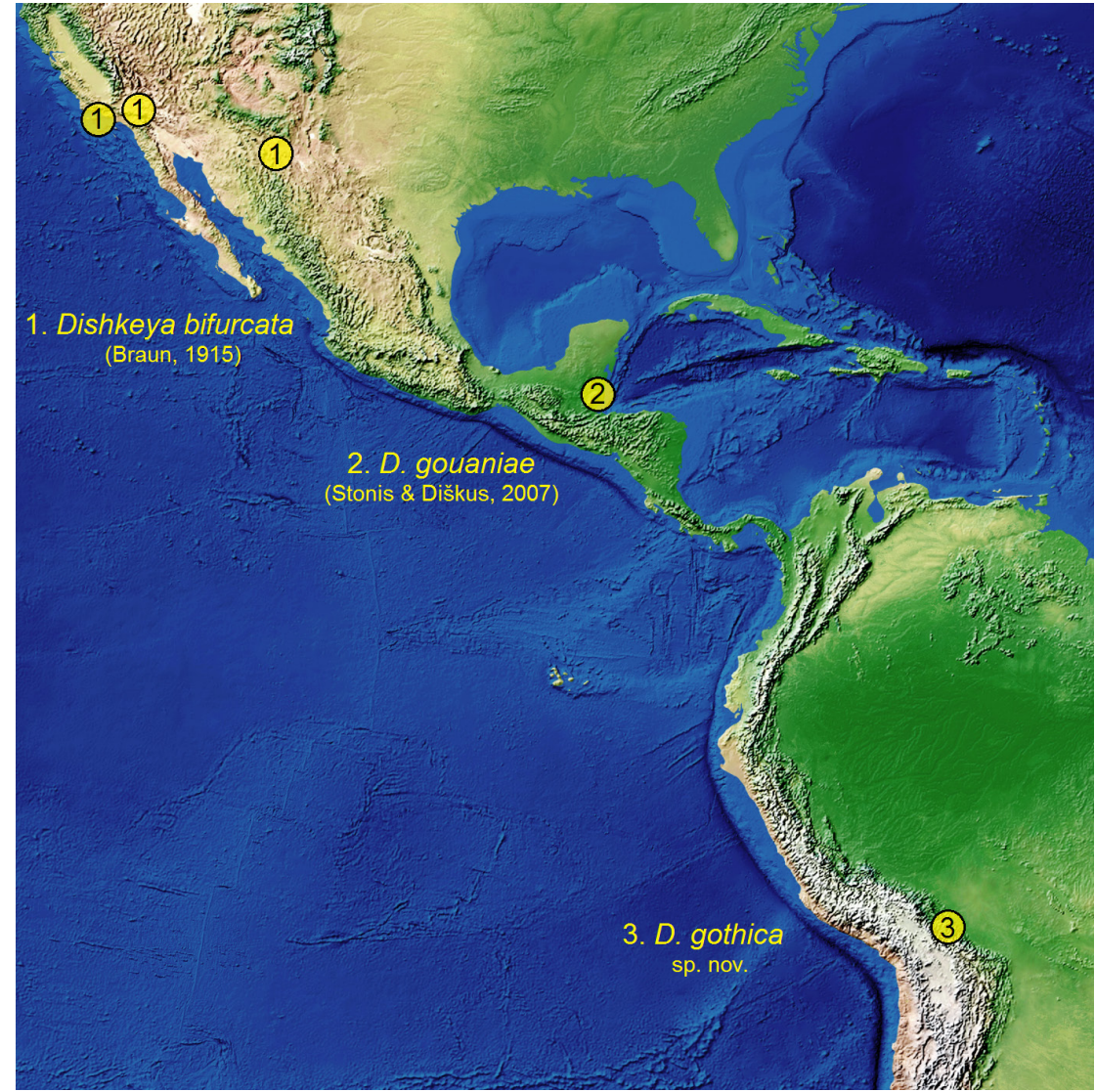

Fig. 27. Currently known distribution of Dishkeya Stonis

\section{ACKNOWLEDGEMENTS}

We thank Prof. Dr Jack Shuster (Universidad del Valle de Guatemala, Guatemala City, Guatemala) and the Consejo Nacional de Areas Protegidas (CONAP) Guatemala, C. A. for the Licencia de Collecta o Aprovechamiento de Vida Silvestre (No. 12900). Jonas R. Stonis thanks Julia Puplesyte-Chambers and the Environmental Programme at the Andes Office of NGO DAR Peru for permission to provide training courses and fieldwork within the project "Rapid assessment of biodiversity plots of critical value in the provinces Chanchamayo and Satipo, Peru, and Bolivia", in cooperation with the Baltic-American Biotaxonomy Institute in 2017-2018. We also greatly appreciate the identification of some host plants by Dr Alfredo F. Fuentes (Universidad Mayor de San Andres, La Paz, Bolivia). We thank Prof. Dr Owen T. Lewis (University of Oxford, U.K.) for the material that he collected in 1997-1998 at Las Cuevas, a research station established jointly by the Forest Department of Belize and the Natural History Museum, London, in 1994.

Jonas R. Stonis thanks Andrius Remeikis for some technical help and Arūnas Diškus for discussion during preparation of this paper. This research was partially funded by a grant (S-MIP-19-30, "DiagnoStics") from the Research Council of Lithuania.

M. Alma Solis thanks Dr Michael Gates, Research Leader, of the Systematic Entomology Laboratory, ARS, USDA, for supporting her participation in this research. Mention of trade names or commercial products in this publication is solely for the purpose of providing specific information and does not imply recommendation or endorsement by the USDA. The USDA is an equal opportunity provider and employer.

Received 30 June 2020 Accepted 13 July 2020 


\section{References}

1. Braun AF. Notes on some species of Tischeria, with descriptions of new species (Lep.). Entomological News, 1915; 26(6): 271-3.

2. Braun AF. Tischeriidae of America North of Mexico (Microlepidoptera). Memoirs of the American Entomological Society. 1972; 28 : $1-148$.

3. Puplesis R, Diškus A. The Nepticuloidea \& Tischerioidea (Lepidoptera) - a global review, with strategic regional revisions. Kaunas: Lutute Publishers; 2003. 512 p.

4. Stonis JR, Diškus A. Distribution of Tischeria gouaniae sp. n. from the tropical forest of Belize - an exotic new addition to the American fauna of Tischeria (Insecta: Lepidoptera: Tischeriidae). Zoological Science. 2007; 24(12): 1286-91. https://doi.org/10.2108/zsj.24.1286

5. Stonis JR, Diškus A, Carvalho Filho F, Lewis OT. American Asteraceae feeding Astrotischeria species with a highly modified, three-lobed valva in the male genitalia (Lepidoptera, Tischeriidae). Zootaxa. 2018; 4469(1): 1-69. doi. org/10.11646/zootaxa.4469.1.1

6. Stonis JR, Diškus A, Paulavičiūtè B, Monro AK. Urticaceae-feeders from the family Tischeriidae: descriptions of two new species and new genus Paratischeria gen. nov. Biologija. 2017; 63(1): 1-22.

7. Stonis JR, Diškus A, Remeikis A, Navickaitè A. Study methods of Nepticulidae: micro-mounts of genitalia structures. In: Stonis JR, Hill SR, Diškus A, Auškalnis T, editors. Selected abstracts and papers of the First Baltic International Conference on Field Entomology and Faunistics. Vilnius: Edukologija Publishers; 2014. p. 32-35.

8. Xu J, Dai X, Liu P, Bai H, Diškus A, Stonis JR. First report on Paratischeria from Asia (Lepidoptera: Tischeriidae). Zootaxa. 2017; 4350(2): 331-44. https://doi: 10.11646/zootaxa.4350.2.8.
Jonas Rimantas Stonis, Maria Alma Solis

\section{DISHKEYA GEN. NOV. - ŠIAURĖS IR PIETŲ AMERIKOJE PAPLITUSI NAUJA AUGALU LAPUS MINUOJANČIU TISCHERIIDAE (LEPIDOPTERA) GENTIS, IŠAIŠKINTA PATIKSLINUS TISCHERIA ZELLER GENTIES DIAGNOZE}

\section{Santrauka}

Straipsnyje aprašoma nauja mokslui Dishkeya gentis ir viena nauja mokslui rūšis $D$. Gothica sp. nov., minuojanti Gouania lupuloides (L.) Urb., Rhamnaceae. Aptariami esminiai diagnostiniai požymiai, leidžiantys identifikuoti Tischeria Zeller ir Dishkeya gen. nov. taksonus. Pateikiamos dvi naujos taksonominès kombinacijos ir išsami naujos genties bei visų priklausančių rūšių genitalinių struktūrų dokumentacija. Mitybos požiūriu Dishkeya gen. nov. yra susijusi su Rhamnaceae augalais (isskaitant Ceanothus L. ir Gouania acq.). Nors šiuo metu naujoji gentis žinoma tik iš kelių geografiškai nutolusių viena nuo kitos vietovių, tačiau manoma, kad Dishkeya gali būti plačiai paplitusi palei vakarinę Šiaurès ir Pietų Amerikos pakrantę.

Raktažodžiai: Dishkeya bifurcata, Dishkeya gothica, Dishkeya gouaniae, nauja rūšis, šeriuotaūsiai 